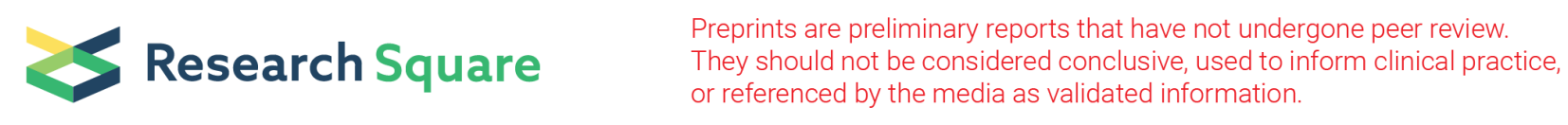

\title{
Disparities in Years of Potential Life Lost Among Racial and Ethnic Groups in Washington State
}

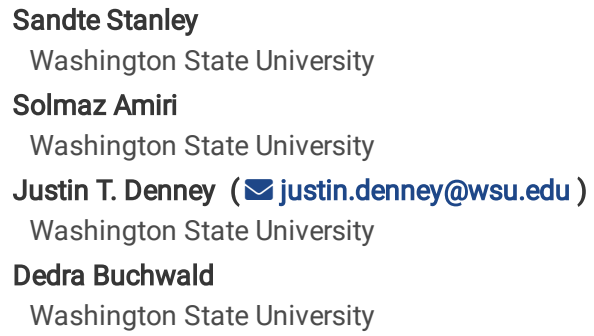

\section{Research Article}

Keywords: premature mortality, years of potential life lost, racial and ethnic disparities

Posted Date: February 17th, 2022

DOl: https://doi.org/10.21203/rs.3.rs-1347618/v1

License: @) (1) This work is licensed under a Creative Commons Attribution 4.0 International License. Read Full License 


\section{Abstract}

Background. Previous research in the United States has documented increased risk of premature mortality for a limited number of racial and ethnic groups but has often failed to account for individual and place-based risk factors.

Methods. We use a measure of years of potential life lost (YPLL) to examine disparities in premature mortality across several racial and ethnic groups in Washington state. Data included nearly 400,000 geocoded death records from Washington state decedents from 2011 to 2018 . Records included information on marital status and educational attainment and were linked to census tract indicators of rurality and area deprivation. We conducted generalized linear mixed models with zero-inflated Poisson distributions to test adjusted associations between racial and ethnic identity and YPLL.

Results. Relative to non-Hispanic whites, non-Hispanic blacks, American Indian and Alaska Natives, Asian or other Pacific Islanders, multiracial, and Hispanic decedents had significantly higher rates of YPLL. Even after important demographic, economic, and geographic controls, Hispanic YPLL was 1.46 times and multiracial 1.38 times higher than whites.

Conclusion. Several distinct racial and ethnic minorities suffer disproportionately from premature mortality in Washington state, hindering these groups from achieving economic stability, political representation, and long lives.

\section{Background}

The disproportionate burden of premature mortality experienced by racial and ethnic minorities compared to their non-Hispanic white (NHW) counterparts is a widely known public health issue [1-4]. American Indian and Alaska Natives (AIANs) and African Americans experience substantially higher rates of death and premature mortality compared to all other racial and ethnic groups across a wide array of causes [5-8]. On average NHWs outlive most racial and ethnic minority groups by nearly 13 years [9]. When entire racial and ethnic groups are at risk of dying prematurely, uncovering information on how many years of life they have lost in association with major sociodemographic factors that contribute to this disparity are crucial and cannot be understood from broad estimates of mortality risk.

Years of Potential Life Lost (YPLL), compared to other mortality estimates, is a particularly valuable measure of premature mortality. YPLL compares observed age at death with life expectancy to estimate the average time an individual would have lived had that individual not died prematurely in proportion to the general population's expected age of death. Compared to other estimates of mortality such as rate ratios or risk, YPLL captures loss resulting from mortality in several domains, social and economic, making this measure stand apart in its ability to expose the impact that premature death has on society.

Premature death has serious economic implications at both state and national levels. This is increasingly important as the youngest of adults in society make up a large portion of the United States work force and their premature mortality negatively impacts the economy. A study conducted by Shiels et al. [4] shows that younger racial and ethnic minorities, such as AIANs age 25-30 years old, were more likely to die prematurely compared to NHWs. Other studies have more explicitly documented the economic benefits of reducing or even eliminating racial and ethnic mortality disparities. A recent study in Minnesota estimated that eliminating racial disparities in preventable deaths alone would produce 1 to 3 billion dollars in economic savings [10]. These savings occur in increased productivity in the labor market but the benefits to reduced disparities in mortality extend to improved and diversified innovation, entrepreneurship, and political leadership as well.

Social determinants of health such as education, income, and place of residence have been examined as causes that drive mortality risk. Socioeconomic status specifically has been coined a fundamental cause of mortality disparities [11]. The theory of fundamental causes states that those who have higher socioeconomic status (SES) are better able to leverage their education and income to access life-saving resources and networks. Lower SES individuals do not have similar access to invaluable resources and higher SES networks and are therefore at higher risk of mortality [12, 13]. Since place of residence is in large part determined by SES it plays an important role in determining mortality and contributing to racial and ethnic differences in mortality [14].

In this paper, we include two well documented contextual determinants of mortality, rurality and socioeconomic disadvantage. Rurality has negative impacts on individual mortality prospects. Compared to residents of urban areas, rural residents have higher risks of all-cause and cause-specific mortality [15-18]. Prior to the 1980s, urban dweller areas faced public health crises such as transmission of infectious diseases and higher rates of mortality due to poor infrastructure and population density issues [19]. Currently, however, that trend has changed and evidence suggests that individuals living in rural areas experience what is described as the rural mortality penalty or excess risk of death for those who reside in rural areas [20,21]. The overwhelming majority of Washington state, 30 of the 39 counties, is designated as rural by the state Department of Health [22].

In addition to rurality, area socioeconomic conditions also impact mortality risk for individuals. In particular, the area deprivation index (ADI) [23], captures important elements of socioeconomic deprivation, economic inequality, and disparities in resource availability across geographic space that are robustly linked to mortality prospects.

In the current study, we provide adjusted estimates of the association of racial and ethnic identity with YPLL for several racial and ethnic minority groups, including decedents of multi-racial identity. We do so after adjusting for several important individual and place-based risk factors for mortality.

\section{Methods}

\section{Data}


Data on registered deaths come from the Washington State Department of Health for the years 2011-2018. The data file included information on decedents' age, sex, race, ethnicity, education, marital status, and residential longitude and latitude. Inclusion criteria for this study were individuals who were 25 years and older at the time of death. People at this age are mature and have a more stable level of education than those 18 and younger [24]. Our final data set includes nearly 400,000 decedents from Washington state over the study period.

\section{Measures}

Outcome variable. YPLL, which gives more weight to deaths occurring at younger ages, was calculated for all decedents [25]. This measure is calculated by subtracting the age at the time of death from a predetermined end point age [25]. The premature mortality benchmark of 75 has been used in U.S., Canadian, Australian, and European studies for quantifying the burden of premature mortality (Adair and Lopez, 2020; Athens et al., 2015; Renard and Deboosere, 2014; Zygmunt et al., 2020). For example, using the end point age of 75, an individual who dies at the age of 25 will have 50 years of life lost, and a person dying at the age of 60 will have 15 years of life lost.

Individual-level explanatory variables. Individual-level variables included race and ethnicity (six categories: $\mathrm{NH}$ white, $\mathrm{NH}$ Black, $\mathrm{NH}$ AlAN, NH Asian, Native Hawaiian or other Pacific Islander (NHOPI), NH multiracial (3 or more racial identities), and Hispanic, sex, educational attainment at time of death, and marital status at time of death.

Community-level explanatory variables. Rurality was classified using the Rural-Urban Commuting Area (RUCA) codes based on decedents' residential location at the time of death. RUCA codes use work commuting information, population data, and measures of urbanization to classify urban and rural areas at the census tract level. RUCA codes of 1-3 were classified as metropolitan areas, codes of 4-6 were classified as micropolitan areas, and codes 7 through10 were classified as small towns and rural areas (Washington State Department of Health, 2017). The ADI, a validated composite score of socio-economic disadvantage, was used to quantify the social and economic characteristics of census tracts (Knighton et al., 2016; Singh, 2003). The ADI was developed based on 17 Census variables in four domains of poverty, housing, employment, and education. We divided ADI scores into terciles of deprivation (1=leastdeprived, 2=middle-deprived, 3=most-deprived).

\section{Statistical Analysis}

Descriptive statistics included measures of central tendency and variability for continuous variables and frequency distributions and percentages for categorical variables. The Interquartile Range (IQR) will be calculated to determine the midpoint of average death for each racial and ethnic group and determine the spread of death across all groups. Generalized linear mixed models with zero-inflated Poisson distributions tested the association between race/ethnicity and YPLL controlling for other explanatory variables. Investigation of data suggested that zero-inflated models are appropriate because of an excessive amount of zeros in the outcome [26]. We treated decedents at level-1 nested within level-2 census tracts. Our models included a random intercept, allowing the likelihood of YPLL to vary across census tracts. This enabled exploration of the associations of both individual- and community-level variables with YPLL while accommodating the clustering of decedents within census tracts.

We start with an adjusted model to examine the relationship between YPLL and race/ethnicity, controlling for sex and marital status. Next, we progressively adjust for education of the decedent and then for residential census tract rurality and area disadvantage. In addition to models on all decedents, we also stratify results and present male and female specific estimates. Associations are presented as incidence risk ratios (IRR) with 95\% confidence intervals (CI). The R-software was used for analysis.

\section{Results}

Table 1 shows characteristics of all decedents age 25 and older in Washington State and also separately for men and women. Less than two percent of deaths were excluded because they occurred before individuals turned 25 . For brevity, we focus on a limited number of characteristics for all decedents here. Decedents were predominantly NH white (88.6\%). Deaths were evenly distributed among men and women during the study period.

Among all decedents, the mean age at death for $\mathrm{NH}$ whites (76.48) was over a decade longer than that of AIAN (64.26), multi-racial (64.74), and Hispanic (65.20) decedents. More consistent with the literature and because the age at death was not normally distributed, we also show the median age at death in Table 1. Large differences exist here as well. Median age of NH whites was 79 (interquartile range [IQR]: 21), while the median age of NH African Americans, NH AIANs, multiracial individuals, and Hispanics were 67 (IQR range: 23), 65 (IQR: 24), 66 (IQR: 27), and 66 (IQR: 29), respectively.

Focusing on the place variables, residential locations with address matching accuracy of $80 \%$ or above were included in the analyses. Most decedents lived in metropolitan census tracts (84.5\%); roughly $9 \%$ lived in micropolitan areas and $7 \%$ lived in small towns or rural areas. Less than four percent (3.9\%) of deaths were excluded because of missing or inaccurate residential address data. Although differences in median age at death across metropolitan (79), micropolitan (79), and rural (77) neighborhoods were minimal the median age of decedents was higher in less-deprived neighborhoods compared to their peers in the mostdeprived neighborhoods $(80[\mathrm{IQR}=22]$ vs. $76[\mathrm{IQR}=23]$.

Table 2 shows the results of generalized linear mixed models on YPLL for decedents who were 25 years and older at the time of death. We report progressively adjusted results but concentrate on the fully adjusted models for all decedents because estimates remained stable with added controls (Model 3 ) for both males (Model 6) and females (Model 9). The control variables in these fully adjusted models demonstrate that never married decedents had IRRs 1.85 times higher than married or cohabiting decedents (Model 3); for males this was 1.92 times higher (Model 6) and for females 1.69 times higher (Model 9).

Decedents with a bachelor's degree or more had 0.90 times the rate of YPLL as decedents with no high school diploma. This protection for YPLL was present for male decedents with a bachelor's degree or more (IRR $=0.84$, Model 6$)$ but not for female decedents $($ IRR $=1.00$, Model 9$)$. For all decedents, living in 
micropolitan and small town or rural neighborhoods carried lower rates of YPLL, compared to decedents in metropolitan neighborhoods. Finally, the ADI illustrates that the more disadvantaged the neighborhood the higher the rate of YPLL.

Compared to NH whites, NH AIANs had a fully adjusted rate 1.29 times higher for YPLL (Model 3). For NH blacks and NH Asian or Other Pacific Islander (NHOPI) decedents, the rate was 1.18 and 1.20 times higher, respectively (Model 3). NH multi-racial and Hispanic decedents had the highest rates compared to $\mathrm{NH}$ whites in Model 3. Multi-racial decedents had a rate 1.38 times higher and Hispanics 1.46 times higher. Confidence intervals suggest that the rate for Hispanic decedents (1.43-1.49) is significantly higher than any other group.

The differences in fully adjusted incident rate ratios between males (Model 6) and females (Model 9) was not statistically significant. However, racial and ethnic minority male and female decedents have higher IRRs for YPLL than their NW white counterparts. Compared to NH white males, racial and ethnic minority males had fully adjusted higher IRRs ranging from 1.16 for $\mathrm{NH}$ blacks to 1.47 for Hispanics (Model 6). For female decedents in Model 9, compared to $\mathrm{NH}$ whites, $\mathrm{NH}$ Asian or NHOPI decedents had rates 1.20 times higher, $\mathrm{NH}$ blacks 1.23 times higher, NH AIANs 1.35 times higher, $\mathrm{NH}$ multi-racial 1.41 times higher, and Hispanics 1.43 times higher.

\section{Discussion}

The burden of premature mortality is widely understood as being a prominent disparity among racial and ethnic minority groups. Within Washington State we found that all decedents who identified as racial and ethnic minorities had higher rates of YPLL compared to NHWs-including NH Blacks, NH AIANs, NH Asian or NHOPIs, NH multi-racial, and Hispanic decedents. Multiple race and Hispanic decedents had the highest rates of YPLL and, even after controlling for important individual and place-based risk factors for mortality, the rate of YPLL for Hispanic decedents exceeded the rate for all other groups. Although the life expectancy of the average person has increased over the last few decades, mortality disparities continue to plague racial and ethnic minorities.

Social, economic, and contextual determinants of health such as marital status, individual educational attainment, rurality, and area-level socioeconomic deprivation all contribute to years of potential life lost and can be addressed through effective social and economic policies. Improvements in risk factors for premature death, such as access to quality education, hold promise to close the gaps in length of life by racial and ethnic identity. Nonetheless, other contributors to racial and ethnic minority gaps in longevity remain to be explored. Future research must address structural racism that restricts access to affordable housing and economic opportunity, prevents equitable political representation, and hampers attaining good health and well-being [27, 28].

These analyses have several notation limitations. First, racial misclassification, typically as white, is a limitation of the data we used in this report. For example, AIAN deaths are undercounted by at least $38 \%$ nationally $[29,30]$, especially on death certificates, the source of our data. Second, we only had data on a single timepoint of decedents' characteristics such as marital status, residential history, and area deprivation. These characteristics may vary over time and can potentially be risk factors for premature mortality. Third, the majority of decedents in our study were NHW, reflecting the demographics of Washington State residents. Our findings may not necessarily reflect patterns in other states with more diverse populations. Fourth, these data do not include deaths from the novel coronavirus, which has been shown to disproportionately impact racial and ethnic minorities [31].

\section{Conclusion}

In summary, despite increasing life expectancy and decreases in the gap in life expectancy between whites and racial and ethnic minority groups, important differences in the mortality experience by racial and ethnic identity remain underexplored. Using YPLL and unique multi-level adjusted analyses on individual decedents, we have shown that racial and ethnic minorities continue to experience a disproportionate burden of premature death in Washington state. Researchers and policy makers must recognize the disproportionate risks to premature mortality and work together to alleviate them through the delivery of better and more accessible targeted health services. In a continually diversifying United States, such disparities represent significant barriers to equity in several social, economic, and health-related realms by racial and ethnic identity.

\section{List Of Abbreviations}

YPLL = Years of potential life lost; NH = non-Hispanic; NHW = non-Hispanic white; AIAN = American Indian or Alaska Native; NHOPI = non-Hispanic other Pacific islander; IRR = incident rate ratio; IQR = inter-quartile range; $A D I$ = area deprivation index; RUCA = rural-urban commuting area; $S E S$ = socioeconomic status; $\mathrm{Cl}=$ confidence interval

\section{Declarations}

Ethics approval and consent to participate

This evaluation of de-identified death records did not use living human subjects and did not require review or approval by an institutional review board for human subjects.

\section{Consent for publication}

Not applicable 
Data on all decedents were purchased from the Washington Department of Health. A request to purchase records can be made at https://www.doh.wa.gov/DataandStatisticalReports/WashingtonTrackingNetworkWTN/DataPortal.

\section{Competing interests}

The authors have no relevant financial or non-financial competing interests to disclose.

Funding

The authors declare that no funds, grants, or other support were received during the preparation of this manuscript.

Author contributions

Study concept and design: SS, JTD; data acquisition: SA; statistical analysis: SA; drafting the manuscript: SS, SA, JTD; Supervision: JTD, DB; Interpretation of data and analysis: SS, SA, JTD, DB

Acknowledgements

Not applicable

\section{References}

1. Fingerhut, L.A. and D.M. Makuc, Mortality among minority populations in the United States. American Journal of Public Health, 1992. 82(8): p. 1168-1170.

2. Jones, K. and C.J. Mansfield, Premature Mortality in North Carolina: Progress, Regress, and Disparities by County and Race, 2000-2010. North Carolina Medical Journal, 2014. 75(3): p. 159-168.

3. Roy, B., et al., Education, Race/Ethnicity, and Causes of Premature Mortality Among Middle-Aged Adults in 4 US Urban Communities: Results From CARDIA, 1985-2017. American journal of public health, 2020. 110(4): p. 530-536.

4. Shiels, M.S., et al., Trends in premature mortality in the USA by sex, race, and ethnicity from 1999 to 2014: an analysis of death certificate data. The Lancet, 2017. 389(10073): p. 1043-1054.

5. Lee-Rodriguez, C., et al., Association of mortality and years of potential life lost with active tuberculosis in the United States. JAMA network open, 2020. 3(9): p. e2014481-e2014481.

6. Li, C., et al., Years of potential life lost and productivity losses from male urogenital cancer deaths-United States, 2004. Urology, 2010. 76(3): p. 528-535.

7. Ruhm, C.J., Drug mortality and lost life years among US midlife adults, 1999-2015. American journal of preventive medicine, 2018. 55(1): p. 11-18.

8. Stahre, M., et al., Peer reviewed: contribution of excessive alcohol consumption to deaths and years of potential life lost in the United States. Preventing chronic disease, 2014. 11: p. 130293.

9. U.S. Centers for Disease Control and Prevention, Leading Causes of Death-Males Non-Hispanic white- United States, 2017. 2019, Office of Minority Health \& Health Equity: Accessed at https://www.cdc.gov/healthequity/lcod/men/2017/nonhispanic-white/index.htm.

10. Nanney, M.S., et al., The economic benefits of reducing racial disparities in health: the case of Minnesota. International journal of environmental research and public health, 2019. 16(5): p. 742.

11. Phelan, J.C., et al., "Fundamental Causes" of Social Inequalities in Mortality: A Test of the Theory. Journal of Health and Social Behavior, 2004. 45(3): $p$. 265-285.

12. Braveman, P.A., et al., Socioeconomic disparities in health in the United States: what the patterns tell us. American journal of public health, 2010. 100(S1): p. S186-S196.

13. Link, B.G. and J. Phelan, Social Conditions as Fundamental Causes of Disease. Journal of Health and Social Behavior, 1995. Extra Issue: p. 80-94.

14. Denney, J.T., J.M. Saint Onge, and J.A. Dennis, Neighborhood Concentrated Disadvantage and Adult Mortality: Insights for Racial and Ethnic Differences. Population Research and Policy Review, 2018. 37: p. 301-321.

15. Hale, N., K. Beatty, and M. Smith, The intersection of residence, community vulnerability, and premature mortality. The Journal of Rural Health, 2019. 35(4): p. 471-479.

16. Henning-Smith, C., et al., Dying Too Soon: County-Level Disparities in Premature Death by Rurality, Race, and Ethnicity. 2019, University of Minnesota: Rural Health Research Center Accessed at https://rhrc.umn.edu/wp-content/files_mf/1552267547UMNpolicybriefPrematureDeath.pdf.

17. James, W.L., All rural places are not created equal: revisiting the rural mortality penalty in the United States. American journal of public health, 2014. 104(11): p. 2122-2129.

18. Pugh, L.D., Geographic Patterns of Years of Potential Life Lost for Mahoning County, Ohio, Census Tracts, 2010. Papers in Applied Geography, 2016. 2(3): p. 342-351.

19. Williams, D.R. and C. Collins, Racial Residential Segregation: A Fundamental Cause of Racial Disparities in Health. Public Health Reports, 2001. 116: $\mathrm{p}$ 404-416.

20. Cosby, A.G., et al., Preliminary evidence for an emerging nonmetropolitan mortality penalty in the United States. American Journal of Public Health, 2008. 98(8): p. 1470-1472.

21. Roth, A.R., et al., Characteristics of place and the rural disadvantage in deaths from highly preventable causes. Social Science \& Medicine, 2020. 245: $\mathrm{p}$. 112689. 
22. Health, W.D.o., Rural and Urban Counties Map. 2017: https://www.doh.wa.gov/Portals/1/Documents/Pubs/609003.pdf.

23. Singh, G.K., Area deprivation and widening inequalities in US mortality, 1969-1998. American Journal of Public Health, 2003. 93(7): p. 1137-43.

24. Van Der Heide, I., et al., The relationship between health, education, and health literacy: results from the Dutch Adult Literacy and Life Skills Survey. Journal of health communication, 2013. 18(sup1): p. 172-184.

25. Gardner, J.W. and J.S. Sanborn, Years of potential life lost (YPLL)-what does it measure? Epidemiology, 1990. 1(4): p. $322-329$.

26. Hoffman, J.P., Regression Models for Categorical, Count, and Related Variables. 2016, Berkeley, CA: University of California Press.

27. Gee, G.C. and C.L. Ford, Structural racism and health inequities: Old issues, New Directions. Du Bois review: social science research on race, 2011. 8(1): p. 115-132.

28. Williams, D.R., Miles to Go Before We Sleep: Racial Inequities in Health. Journal of Health and Social Behavior, 2012. 53(3): p. $279-295$.

29. Frost, F., et al., Correctness of racial coding of American Indians and Alaska Natives on the Washington State death certificate. American Journal of Preventive Medicine, 1994. 10(5): p. 290-294.

30. Stehr-Green, P., J. Bettles, and L.D. Robertson, Effect of racial/ethnic misclassification of American Indians and Alaskan Natives on Washington State death certificates, 1989-1997. American Journal of Public Health, 2002. 92(3): p. 443-444.

31. National Center for Health Statistics, United States Provisional Death Counts. 2021, Centers for Disease Control and Prevention: Accessed at https://data.cdc.gov/NCHS/Provisional-COVID-19-Deaths-Distribution-of-Deaths/pj7m-y5uh.

\section{Tables}

TABLE 1. Characteristics of decedents age 25 and older in Washington State between 2011 and 2018. 


\begin{tabular}{|c|c|c|c|c|c|c|c|c|c|c|c|c|}
\hline \multirow[b]{2}{*}{ Variables } & \multicolumn{4}{|c|}{ All Decedents } & \multicolumn{4}{|c|}{ Male Decedents } & \multicolumn{4}{|c|}{ Female Decedents } \\
\hline & $\mathrm{n}$ & $\%$ & $\begin{array}{l}\text { Age } \\
\text { (mean } \\
(S D))\end{array}$ & $\begin{array}{l}\text { Age } \\
\text { (median } \\
\text { (IQR) }\end{array}$ & $\mathrm{n}$ & $\%$ & $\begin{array}{l}\text { Age } \\
\text { (mean } \\
(S D))\end{array}$ & $\begin{array}{l}\text { Age } \\
\text { (median } \\
\text { (IQR) }\end{array}$ & $\mathrm{n}$ & $\%$ & $\begin{array}{l}\text { Age } \\
\text { (mean } \\
(S D))\end{array}$ & $\begin{array}{l}\text { Age } \\
\text { (median } \\
\text { (IQR) }\end{array}$ \\
\hline \multicolumn{13}{|l|}{ Race/Ethnicity } \\
\hline NH White & 354411 & 88.64 & $\begin{array}{l}76.48 \\
(14.99)\end{array}$ & $79(21)$ & 177318 & 88.04 & $\begin{array}{l}73.82 \\
(15.07)\end{array}$ & $76(22)$ & 177093 & 89.26 & $\begin{array}{l}79.14 \\
(14.43)\end{array}$ & $83(20)$ \\
\hline NH Black & 10266 & 2.57 & $\begin{array}{l}67.34 \\
(16.6)\end{array}$ & $67(24)$ & 5854 & 2.91 & $\begin{array}{l}64.91 \\
(16.02)\end{array}$ & $65(21)$ & 4412 & 2.22 & $\begin{array}{l}70.57 \\
(16.81)\end{array}$ & $71(25)$ \\
\hline NH AIAN & 5043 & 1.26 & $\begin{array}{l}64.26 \\
(16.45)\end{array}$ & $65(24)$ & 2676 & 1.33 & $\begin{array}{l}62.28 \\
(15.92)\end{array}$ & $63(22)$ & 2367 & 1.19 & $\begin{array}{l}66.5 \\
(16.76)\end{array}$ & $\begin{array}{l}68 \\
(24.5)\end{array}$ \\
\hline $\mathrm{NH}$ Asian or NHOPI & 16250 & 4.06 & $\begin{array}{l}73.82 \\
(16.18)\end{array}$ & $77(22)$ & 7798 & 3.87 & $\begin{array}{l}71.1 \\
(16.43)\end{array}$ & $74(23)$ & 8452 & 4.26 & $\begin{array}{l}76.33 \\
(15.53)\end{array}$ & $80(21)$ \\
\hline NH Multi-racial & 3318 & 0.83 & $\begin{array}{l}64.74 \\
(18.19)\end{array}$ & $66(27)$ & 1770 & 0.88 & $\begin{array}{l}62.18 \\
(17.87)\end{array}$ & $63(26)$ & 1548 & 0.78 & $\begin{array}{l}67.68 \\
(18.12)\end{array}$ & $69(27)$ \\
\hline Hispanic & 10522 & 2.63 & $\begin{array}{l}65.2 \\
(18.45)\end{array}$ & $66(29)$ & 5996 & 2.98 & $\begin{array}{l}62.09 \\
(18.21)\end{array}$ & $63(28)$ & 4526 & 2.28 & $\begin{array}{l}69.33 \\
(17.95)\end{array}$ & $72(27)$ \\
\hline \multicolumn{13}{|l|}{ Sex } \\
\hline Female & 198398 & 49.62 & $\begin{array}{l}78.36 \\
(14.9)\end{array}$ & $82(21)$ & & & & & & & & \\
\hline Male & 201412 & 50.38 & $\begin{array}{l}72.85 \\
(15.57)\end{array}$ & $75(22)$ & & & & & & & & \\
\hline \multicolumn{13}{|l|}{ Education } \\
\hline $\begin{array}{l}\text { No high school } \\
\text { diploma }\end{array}$ & 58629 & 14.66 & $\begin{array}{l}76.53 \\
(16.1)\end{array}$ & $81(22)$ & 29346 & 14.57 & $\begin{array}{l}73.45 \\
(16.68)\end{array}$ & $77(24)$ & 29283 & 14.76 & $\begin{array}{l}79.63 \\
(14.88)\end{array}$ & $83(18)$ \\
\hline $\begin{array}{l}\text { High school diploma } \\
\text { or equivalent }\end{array}$ & 158224 & 39.57 & $\begin{array}{l}75.8 \\
(15.65)\end{array}$ & $79(22)$ & 73370 & 36.43 & $\begin{array}{l}71.56 \\
(16.06)\end{array}$ & $74(23)$ & 84854 & 42.77 & $\begin{array}{l}79.46 \\
(14.3)\end{array}$ & $83(19)$ \\
\hline $\begin{array}{l}\text { Some college or } \\
\text { associate degree }\end{array}$ & 102381 & 25.61 & $\begin{array}{l}73.57 \\
(15.64)\end{array}$ & $75(23)$ & 51040 & 25.34 & $\begin{array}{l}70.88 \\
(15.23)\end{array}$ & $72(21)$ & 51341 & 25.88 & $\begin{array}{l}76.23 \\
(15.58)\end{array}$ & $79(23)$ \\
\hline $\begin{array}{l}\text { Bachelor's degree } \\
\text { and above }\end{array}$ & 80576 & 20.15 & $\begin{array}{l}77.04 \\
(14.24)\end{array}$ & $80(20)$ & 47656 & 23.66 & $\begin{array}{l}76.57 \\
(13.69)\end{array}$ & $79(19)$ & 32920 & 16.59 & $\begin{array}{l}77.73 \\
(14.97)\end{array}$ & $81(21)$ \\
\hline \multicolumn{13}{|l|}{ Marital status } \\
\hline Never married & 34673 & 8.67 & $\begin{array}{l}57.19 \\
(18.04)\end{array}$ & $57(25)$ & 23279 & 11.56 & $\begin{array}{l}55.41 \\
(17.08)\end{array}$ & $56(24)$ & 11394 & 5.74 & $\begin{array}{l}60.84 \\
(19.36)\end{array}$ & $60(28)$ \\
\hline $\begin{array}{l}\text { Married or living with } \\
\text { domestic Partner }\end{array}$ & 152781 & 38.21 & $\begin{array}{l}73.25 \\
(13.47)\end{array}$ & 75 (19) & 101103 & 50.20 & $\begin{array}{l}74.37 \\
(13.26)\end{array}$ & $76(18)$ & 51678 & 26.05 & $\begin{array}{l}71.05 \\
(13.59)\end{array}$ & $72(20)$ \\
\hline $\begin{array}{l}\text { Divorced or } \\
\text { separated }\end{array}$ & 75113 & 18.79 & $\begin{array}{l}69.3 \\
(13.61)\end{array}$ & $69(19)$ & 38697 & 19.21 & $\begin{array}{l}67.14 \\
(12.8)\end{array}$ & $67(17)$ & 36416 & 18.36 & $\begin{array}{l}71.59 \\
(14.07)\end{array}$ & $72(20)$ \\
\hline Widowed & 137243 & 34.33 & $\begin{array}{l}86.28 \\
(9.29)\end{array}$ & $88(11)$ & 38333 & 19.03 & $\begin{array}{l}85.18 \\
(9.6)\end{array}$ & $87(11)$ & 98910 & 49.85 & $\begin{array}{l}86.7 \\
(9.13)\end{array}$ & $88(11)$ \\
\hline \multicolumn{13}{|l|}{ RUCA } \\
\hline Metropolitan & 338114 & 84.57 & $\begin{array}{l}75.53 \\
(15.63)\end{array}$ & $79(23)$ & 169291 & 84.05 & $\begin{array}{l}72.68 \\
(15.74)\end{array}$ & $75(22)$ & 168823 & 85.09 & $\begin{array}{l}78.39 \\
(14.97)\end{array}$ & $82(21)$ \\
\hline Micropolitan & 34969 & 8.75 & $\begin{array}{l}76.6 \\
(14.81)\end{array}$ & $79(21)$ & 17658 & 8.77 & $\begin{array}{l}74.34 \\
(14.84)\end{array}$ & $77(21)$ & 17311 & 8.73 & $\begin{array}{l}78.89 \\
(14.43)\end{array}$ & $82(20)$ \\
\hline Small town or rural & 26727 & 6.68 & $\begin{array}{l}74.94 \\
(14.6)\end{array}$ & $77(20)$ & 14463 & 7.18 & $\begin{array}{l}72.99 \\
(14.34)\end{array}$ & $75(20)$ & 12264 & 6.18 & $\begin{array}{l}77.25 \\
(14.57)\end{array}$ & $80(21)$ \\
\hline \multicolumn{13}{|l|}{$\begin{array}{l}\text { Area-deprivation } \\
\text { index }\end{array}$} \\
\hline Less deprived & 137210 & 34.32 & $\begin{array}{l}76.93 \\
(15.25)\end{array}$ & $80(22)$ & 69156 & 34.34 & $\begin{array}{l}74.22 \\
(15.41)\end{array}$ & $77(21)$ & 68054 & 34.30 & $\begin{array}{l}79.67 \\
(14.57)\end{array}$ & $83(20)$ \\
\hline Middle deprived & 136726 & 34.20 & $\begin{array}{l}75.75 \\
(15.31)\end{array}$ & $79(22)$ & 68741 & 34.13 & $\begin{array}{l}73 \\
(15.45)\end{array}$ & $75(22)$ & 67985 & 34.27 & $\begin{array}{l}78.54 \\
(14.64)\end{array}$ & $82(20)$ \\
\hline Most deprived & 125874 & 31.48 & $\begin{array}{l}73.94 \\
(15.81)\end{array}$ & $76(24)$ & 63515 & 31.53 & $\begin{array}{l}71.19 \\
(15.73)\end{array}$ & $73(23)$ & 62359 & 31.43 & $\begin{array}{l}76.75 \\
(15.39)\end{array}$ & $80(22)$ \\
\hline
\end{tabular}


NOTE: NH: Non-Hispanic; AIAN: American Indian or Alaska Native; NHOPI: Native Hawaiian or other Pacific Islander; RUCA: Rural-urban commuting codes; IQR: Interquartile range.

TABLE 2. Generalized linear mixed model of associations between race/ethnicity and years of potential life lost among all decedents 25 years and older at the time of death in Washington State between 2011 and 2018. 


\begin{tabular}{|c|c|c|c|c|c|c|c|c|c|c|c|c|c|c|c|c|c|c|}
\hline & \multicolumn{6}{|c|}{ All Decedents } & \multicolumn{6}{|c|}{ Male Decedents } & \multicolumn{6}{|c|}{ Female Decedents } \\
\hline & \multicolumn{2}{|c|}{ Model 1} & \multicolumn{2}{|c|}{ Model 2} & \multicolumn{2}{|c|}{ Model 3} & \multicolumn{2}{|c|}{ Model 4} & \multicolumn{2}{|c|}{ Model 5} & \multicolumn{2}{|c|}{ Model 6} & \multicolumn{2}{|c|}{ Model 7} & \multicolumn{2}{|c|}{ Model 8} & \multicolumn{2}{|c|}{ Model 9} \\
\hline & IRR & $\mathrm{Cl}$ & IRR & $\mathrm{Cl}$ & IRR & $\mathrm{Cl}$ & IRR & $\mathrm{Cl}$ & IRR & $\mathrm{Cl}$ & IRR & $\mathrm{Cl}$ & IRR & $\mathrm{Cl}$ & IRR & $\mathrm{Cl}$ & IRR & $\mathrm{Cl}$ \\
\hline \multicolumn{19}{|l|}{ Race/Ethnicity } \\
\hline \multicolumn{19}{|l|}{$\begin{array}{l}\text { NH White } \\
\text { (reference) }\end{array}$} \\
\hline NH Black & 1.20 & $\begin{array}{l}1.17 \\
- \\
1.22\end{array}$ & 1.19 & $\begin{array}{l}1.17 \\
- \\
1.22\end{array}$ & 1.19 & $\begin{array}{l}1.16 \\
- \\
1.21\end{array}$ & 1.18 & $\begin{array}{l}1.15 \\
- \\
1.20\end{array}$ & 1.17 & $\begin{array}{l}1.14 \\
- \\
1.20\end{array}$ & 1.16 & $\begin{array}{l}1.13 \\
- \\
1.19\end{array}$ & 1.24 & $\begin{array}{l}1.19 \\
- \\
1.28\end{array}$ & 1.23 & $\begin{array}{l}1.19 \\
- \\
1.28\end{array}$ & 1.23 & $\begin{array}{l}1.18 \\
- \\
1.27\end{array}$ \\
\hline NH AIAN & 1.30 & $\begin{array}{l}1.26 \\
- \\
1.34\end{array}$ & 1.29 & $\begin{array}{l}1.25 \\
- \\
1.33\end{array}$ & 1.29 & $\begin{array}{l}1.25 \\
- \\
1.33\end{array}$ & 1.25 & $\begin{array}{l}1.20 \\
- \\
1.29\end{array}$ & 1.23 & $\begin{array}{l}1.18 \\
- \\
1.27\end{array}$ & 1.23 & $\begin{array}{l}1.19 \\
- \\
1.28\end{array}$ & 1.35 & $\begin{array}{l}1.29 \\
- \\
1.41\end{array}$ & 1.35 & $\begin{array}{l}1.29 \\
- \\
1.42\end{array}$ & 1.35 & $\begin{array}{l}1.28 \\
- \\
1.41\end{array}$ \\
\hline $\begin{array}{l}\text { NH Asian or } \\
\text { NHOPI }\end{array}$ & 1.19 & $\begin{array}{l}1.16 \\
- \\
1.21\end{array}$ & 1.20 & $\begin{array}{l}1.17 \\
- \\
1.22\end{array}$ & 1.20 & $\begin{array}{l}1.17 \\
- \\
1.22\end{array}$ & 1.19 & $\begin{array}{l}1.16 \\
- \\
1.22\end{array}$ & 1.20 & $\begin{array}{l}1.17 \\
\overline{1.23}\end{array}$ & 1.19 & $\begin{array}{l}1.16 \\
\overline{1.22}\end{array}$ & 1.19 & $\begin{array}{l}1.15 \\
- \\
1.22\end{array}$ & 1.19 & $\begin{array}{l}1.16 \\
- \\
1.23\end{array}$ & 1.20 & $\begin{array}{l}1.16 \\
\overline{1} \\
1.23\end{array}$ \\
\hline $\begin{array}{l}\mathrm{NH} \text { Multi- } \\
\text { racial }\end{array}$ & 1.39 & $\begin{array}{l}1.34 \\
- \\
1.44\end{array}$ & 1.38 & $\begin{array}{l}1.33 \\
- \\
1.43\end{array}$ & 1.38 & $\begin{array}{l}1.33 \\
- \\
1.43\end{array}$ & 1.37 & $\begin{array}{l}1.31 \\
- \\
1.43\end{array}$ & 1.36 & $\begin{array}{l}1.30 \\
- \\
1.42\end{array}$ & 1.35 & $\begin{array}{l}1.30 \\
- \\
1.41\end{array}$ & 1.42 & $\begin{array}{l}1.35 \\
- \\
1.50\end{array}$ & 1.42 & $\begin{array}{l}1.34 \\
- \\
1.50\end{array}$ & 1.41 & $\begin{array}{l}1.34 \\
- \\
1.49\end{array}$ \\
\hline Hispanic & 1.47 & $\begin{array}{l}1.44 \\
- \\
1.50\end{array}$ & 1.46 & $\begin{array}{l}1.43 \\
- \\
1.49\end{array}$ & 1.46 & $\begin{array}{l}1.43 \\
- \\
1.49\end{array}$ & 1.49 & $\begin{array}{l}1.45 \\
- \\
1.52\end{array}$ & 1.46 & $\begin{array}{l}1.43 \\
- \\
1.50\end{array}$ & 1.47 & $\begin{array}{l}1.43 \\
- \\
1.50\end{array}$ & 1.43 & $\begin{array}{l}1.38 \\
- \\
1.49\end{array}$ & 1.44 & $\begin{array}{l}1.39 \\
- \\
1.49\end{array}$ & 1.43 & $\begin{array}{l}1.38 \\
- \\
1.49\end{array}$ \\
\hline \multicolumn{19}{|l|}{ Sex } \\
\hline \multicolumn{19}{|l|}{$\begin{array}{l}\text { Female } \\
\text { (reference) }\end{array}$} \\
\hline Male & 1.00 & $\begin{array}{l}0.99 \\
- \\
1.01\end{array}$ & 1.00 & $\begin{array}{l}0.99 \\
- \\
1.01\end{array}$ & 1.00 & $\begin{array}{l}0.99 \\
- \\
1.01\end{array}$ & - & & - & & - & & - & & - & & - & \\
\hline \multicolumn{19}{|l|}{ Marital status } \\
\hline \multicolumn{19}{|l|}{$\begin{array}{l}\text { Married / } \\
\text { cohabitating } \\
\text { (reference) }\end{array}$} \\
\hline Never married & 1.87 & $\begin{array}{l}1.84 \\
- \\
1.89\end{array}$ & 1.85 & $\begin{array}{l}1.83 \\
- \\
1.87\end{array}$ & 1.85 & $\begin{array}{l}1.82 \\
- \\
1.87\end{array}$ & 1.97 & $\begin{array}{l}1.95 \\
- \\
2.00\end{array}$ & 1.93 & $\begin{array}{l}1.90 \\
- \\
1.95\end{array}$ & 1.92 & $\begin{array}{l}1.90 \\
- \\
1.95\end{array}$ & 1.69 & $\begin{array}{l}1.65 \\
-1.73\end{array}$ & 1.69 & $\begin{array}{l}1.66 \\
- \\
1.73\end{array}$ & 1.69 & $\begin{array}{l}1.65 \\
-1.72\end{array}$ \\
\hline $\begin{array}{l}\text { Divorced or } \\
\text { separated }\end{array}$ & 1.10 & $\begin{array}{l}1.09 \\
- \\
1.11\end{array}$ & 1.09 & $\begin{array}{l}1.08 \\
- \\
1.10\end{array}$ & 1.09 & $\begin{array}{l}1.08 \\
- \\
1.10\end{array}$ & 1.17 & $\begin{array}{l}1.15 \\
- \\
1.18\end{array}$ & 1.14 & $\begin{array}{l}1.13 \\
- \\
1.16\end{array}$ & 1.14 & $\begin{array}{l}1.13 \\
-1.16\end{array}$ & 1.01 & $\begin{array}{l}0.99 \\
- \\
1.02\end{array}$ & 1.00 & $\begin{array}{l}0.99 \\
- \\
1.02\end{array}$ & 1.00 & $\begin{array}{l}0.98 \\
- \\
1.01\end{array}$ \\
\hline Widowed & 0.38 & $\begin{array}{l}0.38 \\
- \\
0.39\end{array}$ & 0.38 & $\begin{array}{l}0.37 \\
- \\
0.39\end{array}$ & 0.38 & $\begin{array}{l}0.37 \\
- \\
0.39\end{array}$ & 0.48 & $\begin{array}{l}0.46 \\
- \\
0.49\end{array}$ & 0.46 & $\begin{array}{l}0.45 \\
- \\
0.48\end{array}$ & 0.46 & $\begin{array}{l}0.45 \\
- \\
0.48\end{array}$ & 0.36 & $\begin{array}{l}0.35 \\
- \\
0.37\end{array}$ & 0.36 & $\begin{array}{l}0.35 \\
- \\
0.37\end{array}$ & 0.36 & $\begin{array}{l}0.35 \\
- \\
0.37\end{array}$ \\
\hline \multicolumn{19}{|l|}{ Education } \\
\hline \multicolumn{19}{|c|}{$\begin{array}{l}\text { No high school diploma } \\
\text { (reference) }\end{array}$} \\
\hline $\begin{array}{l}\text { High school dip } \\
\text { equivalent }\end{array}$ & oma or & & 1.01 & $\begin{array}{l}0.99 \\
- \\
1.02\end{array}$ & 1.01 & $\begin{array}{l}0.99 \\
- \\
1.02\end{array}$ & & & 1.02 & $\begin{array}{l}1.00 \\
- \\
1.04\end{array}$ & 1.02 & $\begin{array}{l}1.00 \\
- \\
1.03\end{array}$ & & & 0.98 & $\begin{array}{l}0.96 \\
- \\
1.01\end{array}$ & 0.99 & $\begin{array}{l}0.97 \\
- \\
1.01\end{array}$ \\
\hline $\begin{array}{l}\text { Some college or } \\
\text { degree }\end{array}$ & associa & & 1.03 & $\begin{array}{l}1.02 \\
- \\
1.04\end{array}$ & 1.03 & $\begin{array}{l}1.02 \\
- \\
1.05\end{array}$ & & & 1.00 & $\begin{array}{l}0.99 \\
- \\
1.02\end{array}$ & 1.00 & $\begin{array}{l}0.99 \\
- \\
1.02\end{array}$ & & & 1.07 & $\begin{array}{l}1.05 \\
- \\
1.09\end{array}$ & 1.08 & $\begin{array}{l}1.05 \\
- \\
1.10\end{array}$ \\
\hline $\begin{array}{l}\text { Bachelor's degre } \\
\text { above }\end{array}$ & e and & & 0.90 & $\begin{array}{l}0.89 \\
- \\
0.91\end{array}$ & 0.90 & $\begin{array}{l}0.89 \\
- \\
0.92\end{array}$ & & & 0.84 & $\begin{array}{l}0.83 \\
- \\
0.86\end{array}$ & 0.84 & $\begin{array}{l}0.83 \\
- \\
0.86\end{array}$ & & & 0.98 & $\begin{array}{l}0.96 \\
- \\
1.01\end{array}$ & 1.00 & $\begin{array}{l}0.97 \\
- \\
1.02\end{array}$ \\
\hline \multicolumn{19}{|l|}{ RUCA } \\
\hline \multicolumn{19}{|l|}{$\begin{array}{l}\text { Metropolitan } \\
\text { (reference) }\end{array}$} \\
\hline Micropolitan & & & & & 0.93 & $\begin{array}{l}0.91 \\
- \\
0.96\end{array}$ & & & & & 0.92 & $\begin{array}{l}0.90 \\
- \\
0.94\end{array}$ & & & & & 0.95 & $\begin{array}{l}0.91 \\
- \\
0.98\end{array}$ \\
\hline $\begin{array}{l}\text { Small town or } \\
\text { rural }\end{array}$ & & & & & 0.91 & $\begin{array}{l}0.88 \\
- \\
0.93\end{array}$ & & & & & 0.88 & $\begin{array}{l}0.86 \\
- \\
0.91\end{array}$ & & & & & 0.93 & $\begin{array}{l}0.89 \\
- \\
0.97\end{array}$ \\
\hline
\end{tabular}




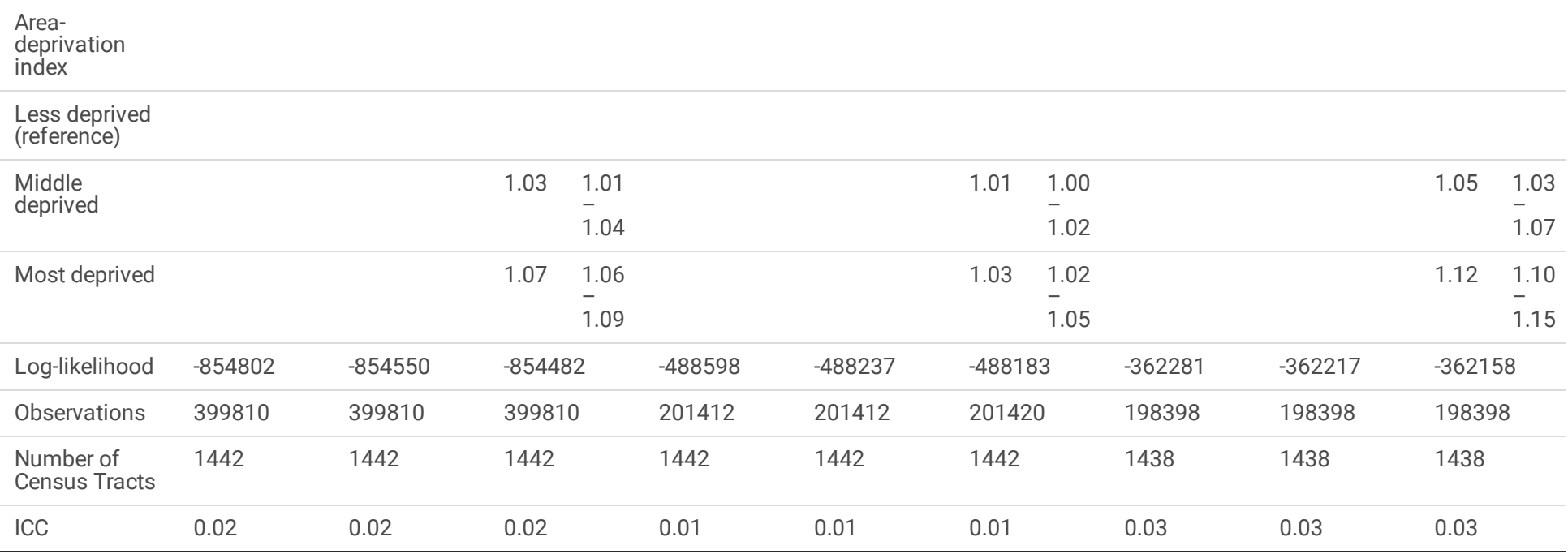

NOTE: NH: Non-Hispanic; AIAN: American Indian or Alaska Native; NHOPI: Native Hawaiian or other Pacific Islander; RUCA: Rural-urban commuting codes; IRR: Incidence risk ratio; $\mathrm{Cl}$ : Confidence interval 